\title{
The Alternative to Occupy? Radical politics between protest and parliament
}

\author{
Emil Husted ${ }^{*}$ and Allan Dreyer Hansen ${ }^{* *}$ \\ "Department of Organization, Copenhagen Business School, Copenhagen, Denmark, \\ www.cbs.dk/en/staff/ehioa
}

"Department of Social Sciences and Business, Roskilde University, Roskilde, Denmark, www.ruc.dk/ adh

\begin{abstract}
In this paper, we compare the political anatomy of two distinct enactments of (leftist) radical politics: Occupy Wall Street, a large social movement in the United States, and The Alternative, a recently elected political party in Denmark. Based on Ernesto Laclau's conceptualization of 'the universal' and 'the particular', we show how the institutionalization of radical politics (as carried out by The Alternative) entails a move from universality towards particularity. This move, however, comes with the risk of cutting off supporters who no longer feel represented by the project. We refer to this problem as the problem of particularization. In conclusion, we use the analysis to propose a conceptual distinction between radical movements and radical parties: While the former is constituted by a potentially infinite chain of equivalent grievances, the latter is constituted by a prioritized set of differential demands. While both are important, we argue that they must remain distinct in order to preserve the universal spirit of contemporary radical politics.
\end{abstract}

Keywords: Radical Politics, Radical Movements, Radical Parties, Discourse Theory, Ernesto Laclau, Universalism, Particularism, Occupy Wall Street, The Alternative

Acknowledgement: First of all, we would like to thank the anonymous reviewers and the editorial team at tripleC for their constructive comments. Secondly, we would like to thank Ursula Plesner and Sine Nørholm Just at Copenhagen Business School for their equally valuable feedback on earlier drafts of this paper.

\section{Introduction}

Crowds are forcing the Left to return again to questions of organization, endurance and scale. Through what political forms might we advance? For many of us, the party is emerging as the site of an answer. (Dean 2016, 4)

On September 17, 2011, scores of protesters responded to a call from the Canadian magazine, Adbusters, by pouring into New York's financial district to join the occupation of Wall Street, the so-called "financial Gomorrah of America" (Adbusters 2011b). The occupation, which quickly became known as Occupy Wall Street (OWS), was said to mark a shift in revolutionary tactics, in which a swarm of people would repeat one single demand. Though without settling on such a demand, the OWS protesters quickly descended on the nearby Zuccotti Park to create a miniature version of direct democracy based on active participation and consensus-based decision-making (Welty et al. 2013). For months, however, the struggle over demands waged, with one group arguing that the movement should present the established system with a list of tangible demands, and an anti-demand group arguing otherwise (Gitlin 2012). 
Ultimately, OWS completely abandoned the pursuit of demands. The diversity of the movement's participants and the principle of "modified consensus" at general assemblies made it virtually impossible for the movement to settle on particular objectives (Kang 2012). Accordingly, OWS ended up as an irreconcilable crowd without any kind of positive articulation of political demands.

Even though several prominent scholars have celebrated the movement's aversion to parliamentary politics as a way of de-legitimizing the established system (e.g. Butler 2012; Graeber 2012; Hardt and Negri 2011; Pickerill and Krinsky 2012), OWS has received equally harsh criticism for its unwillingness to engage with existing political institutions. For instance, as Deseriis and Dean (2012, n.p.) argue: "the movement has to dispel the illusion that all proposals and visions are equivalent as long as they are democratically discussed, and begin to set priorities to a truly transformative and visionary politics". Similarly, Roberts (2012) argues that one reason why OWS "failed" to disrupt the neoliberal status quo was its inability to issue concrete demands and its reluctance to forge strategic alliances with established groups or politicians. Building on similar assumptions, Epstein (2012) makes a distinction between what she calls "resistance" and "social change", with OWS belonging to the former category, which is concerned with drama and spectacle, while the latter involves actually thinking about "how we get from where we are to the society that we want" (Epstein 2012, 81-82). To many observers - as well as participants - OWS thus failed the progressive agenda because of its minimal impact at the level of 'realpolitik'.

On September 17, exactly two years later, the former Minister of Culture in Denmark, Uffe Elbæk, left the Social-Liberal Party in order to launch a new political project called The Alternative. The stated purpose of The Alternative was to challenge the unsustainable program of neoliberalism and the pro-growth agenda by representing and promoting social, economic, and environmental alternatives to the current state of affairs. Besides this grand objective, however, The Alternative started out with no political program whatsoever. All they had was a manifesto and six core values (The Alternative 2016). With inspiration from the open-source community, the program was later developed through so-called "political laboratories" in which anyone could participate, regardless of political convictions (The Alternative 2014). During the national elections in June 2015, The Alternative entered the Danish Parliament with almost five percent of the votes. As such, both in terms of processual arrangements and the initial lack of particular demands, The Alternative could be viewed as an attempt to institutionalize the spirit of movements like OWS.

In this paper, we compare the political anatomy of OWS and The Alternative and argue that they should be viewed as two distinct enactments of contemporary radical politics. While OWS is viewed as an example of "critique as withdrawal", The Alternative is characterized as an example of "critique as engagement" (Mouffe 2009). ${ }^{1}$ Accordingly, we suggest that, at least on a conceptual level, The Alternative could be seen as a continuation of OWS' project; as a project that began where OWS ended by presenting the established system with a detailed list of political demands. Drawing on the vocabulary of Laclau (1996a; 1996b; 2001), we conceptualize The Alternative's transformation from a loosely defined movement to a well-defined political party

\footnotetext{
${ }^{1}$ In this categorization, we follow Laclau and Mouffe's notion of politics as articulations, which entails forging connections with different demands and groups (Laclau and Mouffe 1985, 105). It is, of course, only in this light, and not in the light of, for instance, Hardt and Negri's (2004) notion of the multitude as separate identities and points of resistance that OWS appears as an instance of withdrawal.
} 
as a move from a position of universality towards a position of particularity. In this case, the institutionalization of radical politics thus entails a particularization of The Alternative's political project, which ultimately sparks a greater need for political management in order for the party to maintain its universal appeal and, by implication, its radical identity. In conclusion, we use this conceptualization to propose a distinction between what we call "radical movements" and "radical parties": While the former is constituted by a potentially infinite chain of equivalent grievances, the latter is constituted by a prioritized set of differential demands.

The paper is structured as follows. We start by briefly reviewing the discourse theory of Laclau and Mouffe $(1985 ; 1987)$. Here, special attention will be paid to explaining Laclau's (1996a; 1996b) conceptualization of the unbridgeable chasm between 'the universal' and 'the particular', which constitutes the backbone of the paper's theoretical framework. Building on those insights, we proceed to discuss the nature of radical politics today. ${ }^{2}$ A key argument here will be that the word 'radical' implies negativity and otherness, which makes it particularly difficult to advance positive articulations of radical politics. We will refer to this difficulty as the problem of particularization. After this theoretical exercise, we continue with a section on the methodological considerations guiding the forthcoming analysis. This leads us to the actual analysis of OWS and The Alternative, in which we tease out the difficulties of institutionalizing radical politics through parliament. This analysis is dovetailed by a concluding discussion of radical movements and radical parties. Building on key insights from the examination of OWS and The Alternative, we will attempt to distinguish between those two types of organizations. This distinction allows us to argue that both movements and parties are of great importance to contemporary radical politics, as long as they remain discrete parts of the "mosaic left" (Urban 2009). Finally, we propose possible avenues for further research.

\section{Discourse Theory and Radical Politics}

Laclau and Mouffe's discourse theory was initially developed as an attempt to advance the socialist agenda by providing the academic Left with new thinking tools that would exceed the explanatory power of classical Marxist theory (Laclau and Mouffe 1987). By replacing the economic determinism of Marxist thinking with a poststructuralist focus on pluralism and contingency, Laclau and Mouffe sat out to create a theory that was capable of explaining the crisis of traditional leftist politics and the concomitant proliferation of 'new social movements' from the late 1960s and onwards. Even though this theoretical venture started with some of especially Laclau's earlier writings (e.g. Laclau 1977), the theory rose to prominence with the publication of the seminal work, Hegemony and Socialist Strategy (Laclau and Mouffe 1985). Not only did this book spark intense debate amongst leftist scholars and practitioners about the true nature of socialist politics, it also helped pave the way for a new understanding of democracy, and hence, a new conception of politics altogether.

Drawing on the work of Gramsci (1971), Laclau and Mouffe place the concept of hegemony at the heart of political analysis. Instead of merely associating hegemony with leadership and superiority (as is often the case in mainstream political science), they appropriate the concept to explain how political projects generally emerge and become dominant. To Laclau and Mouffe, hegemony is understood as the articula-

\footnotetext{
${ }^{2}$ It should be noted that while this paper solely deals with leftist radical politics, the argument conveyed throughout the text equally applies to other enactments of radical politics. So when we later speak of a 'mosaic left', one could just as well talk about a 'mosaic right'.
} 
tory practice of expanding a discourse - or a series of discourses - into what Gramsci called a "national-popular collective will" $(1971,125)$. Hegemony is achieved, they argue, when unity is established in a concrete social formation (Laclau and Mouffe $1985,7)$, and in that way, the concept of hegemony becomes closely related to another slippery concept in political science, namely the notion of ideology (Laclau 1997). In practice, a discourse becomes hegemonic by provisionally fixing the meaning of the social through the articulation of a signifying system, which is structured around sufficiently empty signifiers (also referred to as "nodal points" [Laclau and Mouffe 1985, 112]). Put briefly, empty signifiers are signifiers that lack a signified. Instead of pointing to something positive within a signifying system, empty signifiers point to the outside of the system and, by implication, to the very limits of the system: Its so-called "radical otherness" (Laclau 1996b, 52). Accordingly, the strictly positive character of that which is signified by empty signifiers is what Laclau terms the 'systematicity of the system', meaning that elusive universal beyond the actual particularity of the elements involved (Laclau 1994, 169).

A good example of an empty signifier is the word 'sustainability', which has recently become a frequent buzzword in leftist politics and which plays a central part in the political project of The Alternative in particular. Even though most people feel they know what the word means, it always escapes attempts to define it in any consensual way. This is the case because the term does not point to anything particular within a signifying system. It holds little positive meaning and cannot be substituted for more specific terms like, for instance, 'degrowth' or 'veganism'. Instead, 'sustainability' is the empty signifier giving sense to the signifying system in its totality. In this way, the emptiness of 'sustainability' points to the very limits of the system and to that which lies beyond the system, namely the ungraspable calamities of climate change. Of course, this inherent emptiness allows for a lot of window-dressing on the part of politicians and decision-makers, but it likewise provides environmentalists with the possibility of articulating various progressive initiatives within a shared frame of reference (see Brown 2016 for a discussion of this matter). Hence, contrary to most common understandings, the concept of empty signifiers is not used by Laclau as a pejorative label for a destitute kind of politics, but rather as a defining feature of politics altogether.

As Laclau (1994) notes, empty signifiers are important to politics for several reasons. For one, empty signifiers are able to mobilize and represent a wide range of political identities, precisely because they do not signify anything particular. By not signifying (and thus prioritizing) particularities, empty signifiers are able to structure the identities of a signifying system in equivalential chains. An equivalential chain is a chain of political identities that have surrendered some of what initially made them differential in order to unite against a common adversary (i.e. the system's constitutive outside). As such, while the equivalential chain provides the individual identities with stability and solidarity, it likewise curbs their autonomy (Laclau 2005, 129). This is why Laclau refers to empty signifiers as signifiers of "the pure cancellation of all difference" (Laclau 1994, 170). Secondly, empty signifiers are important to politics because they help build antagonistic relations towards opposing forces. As both Laclau and Mouffe have shown, the production of social antagonisms is a prerequisite for all political projects, as the fantasy of a completely reconciled society remains unachievable (Laclau and Mouffe 1985, 122; Mouffe 2005). As we shall see, both OWS and The Alternative are founded on the erection of antagonistic frontiers demarcating themselves from a radical otherness. In both cases, it is 'the establishment' that is 
excluded from the system, which enables the projects to mobilize an almost infinite chain of counter-hegemonic identities.

\subsection{The Universal and the Particular}

Hegemony is thus not only the name of a political logic but also the name of a process that brings us from the undecidable terrain of discursivity (the ontological level) to the decidable level of discourse (the ontic level) by provisionally fixing the otherwise contingent character of the social (Torfing 1999, 102). Another way of conceiving this hegemonic process is through the asymmetrical relationship between what Laclau calls "the universal" and "the particular" (1996a; 1996b). Usually when political projects emerge and become hegemonic, they undergo a process of universalisation in which a particular struggle is detached from its local context and transformed into a universal project capable of representing a host of political identities (Laclau 2001). A recent example of this might be the transformation of the Pirate Party from a Swedish protest party concerned with copyright laws and Internet freedom to an international party concerned with a wide variety of political struggles (Miegel and Olsson 2008). In that way, the Pirate Party assumes the task of representing something much bigger than a particular struggle about copyright laws in Sweden, which is ultimately what led to the project becoming universal.

As such, particular identities (or struggles or demands) are differential, in the sense that they can be clearly separated from other particularities. As such, all social groups that are structured around specific interests can be characterized as particular identities (Laclau 2001, 6). On the other hand, universal identities are former particular identities that have surrendered what initially made them differential in order to represent what Laclau calls the "absent fullness of the community" $(1997,304)$. Whenever an identity assumes the task of representing the community in its entirety, it becomes universal and, hence, hegemonic. The hegemonic process is thus constituted by a 'dialectic' relationship (without Aufhebung) between the universal and the particular as two unbridgeable levels of the social. The reason why the chasm between universality and particularity is unbridgeable is related to the plurality of the social and the impossibility of reaching a fully reconciled society. In fact, the preservation of this chasm is a fundamental trait of democracy. The moment when the universal becomes commensurable with a certain particularity is the moment we enter the world of totalitarianism (Laclau 2001, 12).

By definition, the universal is an unachievable beyond, which can only be manifested by an empty signifier. Accordingly, the universal identity must itself lack positive content, as the attribution of positive content to a universal identity inevitably entails a prioritization of some kind of particularity (Laclau 2001, 10). The dialectic relationship between the ongoing production of emptiness, closely associated with the universal, and the specificity of the particular will be paramount to our forthcoming analysis. Here, we shall see how OWS was forced to abandon their initial quest for particularity and adopt a highly universal identity, and how The Alternative - contrary to OWS - began as a highly universal project but ended up with the perhaps most particular political program of all parties in the Danish parliament. These opposing transformations are what distinguish the two organizations and, ultimately, what constitutes the difference between radical movements and radical parties. However, before we get ahead of the argument, let us first consider the nature of contemporary radical politics. 


\subsection{From Identity Politics to Radical Politics}

With the rise of the Alterglobalization movement, famously initiated during the Battle of Seattle in 1999, a new type of radical politics seems to have emerged (Maeckelbergh 2009; Taylor 2013). Previously, the label of radical politics was reserved for the many 'new' social movements that transpired during the latter part of the 20th century, such as second wave feminism and the African-American civil rights movement (Newman 2007, 174). These movements are often associated with the term 'identity politics' because they advocated freedom and recognition for clearly designated constituencies. In other words, rather than trying to represent 'the people' as a whole, they struggled for the recognition of oppressed identities by seeking to transform the dominant conception of specific groups of people (Young 1990).

Drawing on a Laclauian vocabulary, one could argue that the new social movements were chiefly concerned with the assertion of particular identities within a broader discourse of postmodernity, in which the grand narratives of modernity had been replaced by an incommensurable sea of differences (Laclau 1985, 41). Instead of building hegemonic projects through the articulation of universalistic ideas, the goal of identity politics was simply to secure the recognition of yet another particular identity. However, as Newman (2007) makes clear in his book Unstable Universalities, radical politics after the Alterglobalization movement has another agenda. Rather than fighting for the rights of so many differences, contemporary radical politics has revived the Left's interest in universalities. As explained by Laclau's former supervisor, Hobsbawm $(1996,43)$ :

The political project of the Left is universalist: it is for all human beings. However we interpret the words, it isn't liberty for shareholders or blacks, but for everybody. It isn't equality for all members of the Garrick Club or the handicapped, but for everybody. It is not fraternity only for old Etonians or gays, but for everybody. And identity politics is essentially not for everybody but for the members of a specific group only.

Contrary to the particularistic objectives of identity politics, contemporary radical politics assumes the task of representing the pure being of 'the people' (as a whole) by negating that which threatens its very existence (Laclau 2006). The difference between identity politics and what we call contemporary radical politics can thus be summarized as a difference between abundance and lack (Tønder and Thomassen 2005). While the former seeks to offer recognition to an abundance of particularities, the latter operates with a constitutive lack as its only point of unity. As previously alluded to, this lack is caused by the emptiness of universality and the associated cancellation of particular differences (Laclau 1996a). It is precisely the lack of positive content, and the shared opposition towards established "positives", that unifies political organizations like the Alterglobalization movement (Newman 2007). And as we shall see, this also applies to OWS and the initial stage of The Alternative.

Radical politics, conceived as involving the production of emptiness through the articulation of empty signifiers, may thus be conceptualized as politics based on negativity and otherness. Of course, this does not mean that there is nothing positive or meaningful about radical politics. It merely means that the defining feature of radical politics is negativity towards 'the establishment'. This kind of negativity does, however, characterize a wide range of political forms like, for instance, populism (La- 
clau 2005). As such, The Alternative might appear as a populist party, and the early dominance of equivalential logics as well as the undeniably decisive role played by its leader, Uffe Elbæk, arguably points in that direction. However, one of the defining features of populism is the explicit articulation of 'the people' as a figure being threatened by an adversary but also as having the potential to overcome this threat. In the case of The Alternative, 'the people' do not play a dominant role (at least not explicitly). Likewise, despite Elbæk's central position, the organization of The Alternative points strongly in the opposite direction. The so-called political laboratories, in which everyone is invited to shape the party's policies, suggest that it is neither a populist nor a leader's party.

Our conception of radical politics has a series of consequences for political organizations that, like OWS and The Alternative, consider themselves radical. Perhaps the most important implication for this paper concerns the problem of institutionalizing radical politics through the parliament. This is the case because, in the context of radical politics, the move from protest to parliament entails a move from a position of universality towards a position of particularity. ${ }^{3}$ This transformation is caused by the need to respond to the logic of the established system, which requires a positive articulation of political demands. The task of attributing positive content to an otherwise universal identity is difficult for two reasons: First, it cuts short the equivalential chain, which essentially means that the scope of representation is significantly narrowed. Secondly, it differentiates and isolates demands that were previously united in opposition to a common adversary. The most pertinent consequence of these two processes is that the move from universality towards particularity risks cutting off supporters who no longer feel represented by the project. In other words, the more particular a political project gets, the harder it gets to claim to represent 'the people' as a whole (Laclau 2005, 89). In what follows, we will refer to this as the problem of particularization.

\section{A Brief Note on Methods}

Even though the forthcoming analysis revolves around the empirical story of two "critical cases" (Flyvbjerg 2006), the gist of this paper is thoroughly theoretical. That is, the main purpose of the paper is to raise and unfold a general problem inherent to all radical political projects that seek to particularize an otherwise universal identity. Thus, the purpose of the paper is not to ponder the empirical complexity of either case or to investigate the problem of particularization across a representative sample of political organizations. Instead, the point is to strategically appropriate two illustrative cases as a way of allowing for a logical deduction of the type: "If this is (not) valid for this case, then it applies to all (no) cases" (Ibid., 230). Naturally, this does not render methodological considerations obsolete, which is why we below shed some light on the way in which data has been collected and analyzed for the purpose of the present paper.

First of all, it should be noted that this paper is part of a larger study of The Alternative's transformation from movement to party carried out by the first author. The empirical foundation of the larger study consists of well over 1000 pages of written material, 34 semi-structured interviews, and almost 200 hours of participant observa-

\footnotetext{
${ }^{3}$ In the context of identity politics, the opposite would most likely be the case. Since identity politics is concerned with the assertion of isolated particularities, the entry into parliament would most likely entail a universalization of the political project, not a further particularization. This was, for instance, the case for the Pirate Party.
} 
tion, all of which was collected and conducted during 18 months, from May 2014 to October 2015. Hence, even though the present paper relies on only a handful of documents, the remaining bulk of data has naturally helped us arrive at the points that are conveyed throughout the text. For instance, when we, towards the end of the analysis, suggest that The Alternative has managed to maintain a degree of universality despite the party's sudden claim to particularity, this argument is supported by more data than what is explicitly presented here (most notably observations and interviews with different members of The Alternative). Unfortunately, limitations of space prevent us from unfolding the richness of that data here.

Now, turning to the data that is examined in this paper, the following analysis consists of a close reading of a few central documents. These documents have all played a crucial role in defining the political projects of OWS and The Alternative, and they continue to shape the way supporters relate to both organizations. In the case of OWS, two documents are examined: The first is Adbusters Magazine's initial call to "occupy Wall Street", manifested in a now iconic poster and an associated email (Adbusters 2011a; 2011b). The second is The Declaration of the Occupation of New York City, which serves as the movement's first official statement (Occupy 2011). In the case of The Alternative, we rely on a total of seven documents, including the party's manifesto (The Alternative 2013b) and two versions of the political program (The Alternative 2014; 2015b). The reason for this unevenness of data has to do with the paper's main objective. As mentioned, besides splitting the difference between radical movements and radical parties, the paper's chief goal is to empirically demonstrate what we call the problem of particularization, which is a problem faced by The Alternative and evaded by OWS. As such, the analysis of OWS, while certainly an interesting case in and of itself, primarily serves to set the stage for the introduction of The Alternative.

Analytically, we approached all of the documents through Laclau's conceptualization of the universal and the particular, which meant that we sat out to explore whether these documents point to particularities within the two organizations, or whether they, instead, point to some kind of radical otherness. In practice, we identified particularity as the positive articulation of specific political objectives. This meant that whenever the documents contained actual policy proposals or suggestions for demands, we interpreted this as signs of particularity. In contrast, whenever the documents only contained negative claims about some externality, or when they predominantly revolved around empty signifiers, we interpreted this as a sign of universality.

\section{Analysis: Institutionalizing Radical Politics}

Before proceeding to the analysis, it should be noted that there are important differences between Danish and American forms of government. For instance, while the Danish system is built on proportional representation, which tends to favour multipartism, the American system is built on plurality voting, which (according to Duverger's law) tends to favour a two-party system. Besides this, the electoral threshold in Denmark stands at a mere 2 percent, making it comparatively easier for extraparliamentarian groups in Denmark to enter parliament. As such, one might argue that OWS and The Alternative are part of two somewhat incommensurable realities. And indeed, this would have been the case, had we set out to explain why The Alternative engages with the state and why OWS did not. This is, however, not the purpose of the forthcoming analysis. As stated in the introduction, the purpose is to tease out the theoretical implications of institutionalizing radical politics. We will do so 
by first recounting the story of OWS, and the movement's aversion to parliamentary politics, as a way of setting the stage for the introduction of The Alternative. The way the two organizations move between protest and parliament, universality and particularity, will ultimately assist us in characterizing OWS and The Alternative as two distinct enactments of radical politics: One that withdraws from the state and one that engages with the state and, consequently, the problem of particularization.

\subsection{Occupy Wall Street: 'A movement without demands'}

Even though the Occupy movement was a product of many people's shared ambitions to bring the spirit of the Arab Spring and the Spanish Indignados to America (Kroll 2011), most observers trace the birth of OWS back to a poster issued by $A d$ busters Magazine in July 2011. The poster shows a ballerina dancing atop Wall Street's famous statue of a charging bull. Right above the ballerina, a text reads: "What is our one demand?" (Adbusters 2011a). Accompanying the poster was an email written as a "tactical briefing" to all those "redeemers, rebels and radicals out there". Besides encouraging its receivers to flood Wall Street on September 17, the email likewise suggested that a shift in revolutionary tactics was underway. Instead of attacking the system "like a pack of wolves", which presumably was the tactic of the Alterglobalization movement, the occupation of Wall Street would be more like a swarm of people repeating one easily comprehensible demand. In fact, the email even contained a suggestion for one such demand, namely the appointment of a "presidential commission to separate money from politics" (Adbusters 2011b).

As such, OWS began as an attempt to create a highly particularized movement, initially only concerned with articulating one single demand. However, once the first protesters assembled in Zuccotti Park, just north of Wall Street, it quickly dawned on everyone that settling on one specific objective would be more than difficult. While some participants debated whether OWS should focus on "ending corporate personhood" or "getting money out of politics" (Kang 2013, 59), the movement's anarchist wing advocated a complete withdrawal from the state and, hence, an anti-demand approach to radical politics (Graeber 2013). Zeroing in on one demand became even harder when OWS adopted a 90\% threshold at general assemblies (what was called "modified consensus"), which made it virtually impossible for participants to resolve any issue related to the question of demands. So, instead of presenting the established system with one tangible demand - or even a list of demands - the movement decided to refrain from advancing positive articulations of political objectives. In that way, OWS officially abandoned the pursuit of particularity and adopted a highly universal identity represented by the well-known meme, "We are the 99 percent" (van Gelder 2011).

At a general assembly on September 29, the movement's participants voted in favour of adopting a document entitled The Declaration of the Occupation of New York City (Occupy 2011). In the absence of positive articulations, the declaration contained a long list of negatively framed grievances targeted at an unspecified actor called 'they'. In total, the declaration lists no less than 21 accusations regarding a wide range of issues. For instance, while the first grievance addresses the topic of illegal foreclosures, the third concerns gender and race inequality at the workplace, and while the fifth grievance concerns animal welfare, the twelfth points to issues of press freedom infringements. At the very end of the list, a footnote reads: "These grievances are not all-inclusive" (Ibid.). Two things about this declaration are immediately interesting to this paper. The first has to do with the seemingly infinite sequence of grievances. From a Laclauian point of view, this sequence is easily inter- 
preted as an "equivalential chain". As explained in the theory section, an equivalential chain is a series of non-prioritized identities united against a common adversary, thereby obtaining a high degree of universality (Laclau 2005, 77). In accordance with the definition of equivalence, none of the listed grievances are prioritized or hierarchically ordered, and they all share the same overriding dissatisfaction with 'they'. This leads us to the second point of interest in OWS' declaration, namely the erection of an antagonistic frontier between 'the people' (represented by OWS) and 'they'. It takes little knowledge of OWS to realize who they are. 'They' is, of course, the name of the movement's logical counterpart, the wealthiest 1 percent of the population, who function as the constitutive outside of the 99 percent (van Gelder 2011).

The equivalential chain, and the associated splitting of the social into two opposing camps - the people and its Other - is a key feature of all universal political projects and, thus, a central part of any radical politics (Newman 2007; Laclau 2006). As such, The Declaration of the Occupation of New York City helps establish the universal character of OWS' political project by ultimately cancelling all particularity through the articulation of "the 99 percent" as an empty and radically inclusive signifier (Maharawal 2013). Towards the end of 2011, OWS revived the discussion of demands by issuing an official statement against the "Stop Online Piracy Act" (Kang 2014, 80), but by then the movement had already sealed its legacy as "a movement without demands" (Deseriis and Dean 2011). Due to the lack of positive articulations, OWS continued to grow wider in scope, and when the movement later substituted its physical presence for purely online endeavours, the proliferation of grievances exploded (Husted 2015). ${ }^{4}$

It is an ongoing debate whether OWS had any impact on 'realpolitik'. While some argue that the recent US presidential nominations were notably influenced by the overall message of OWS (Levitin 2015), the main conclusion seems to be that, besides a few unauthorized co-optations by politicians like Al Gore and Nancy Pelosi, the movement has had little "assessable impact" on parliamentary politics (Malone and Fredericks 2013). The general agreement about the lack of impact has earned OWS a reasonable amount of criticism from observers and participants alike (e.g. Chomsky 2012; Epstein 2012; Perlstein 2012). In fact, some even argue that OWS 'failed' because of its unwillingness - or inability - to issue concrete demands and its reluctance to forge strategic alliances with parts of the established system (Ostroy 2012; Roberts 2012). ${ }^{5}$ Dean, one of the more avid critics, has gone to great lengths to show why the movement's anarchist-inspired aversion to parliamentary politics was, in fact, a misguided attempt to preserve the egalitarian ethos of the initial occupation (Deseriis and Dean 2011; Dean 2012a; Dean 2012b). In her most recent book, Dean (2016) makes the argument that crowds, such as the one constituting OWS, are inherently non-political until they abandon "horizontalism" as an organizing principle and begin to set priorities by articulating a clear political orientation. In other

\footnotetext{
${ }^{4}$ Research on OWS within media studies suggests that social media platforms, such as Facebook and Twitter, played a crucial role in allowing the movement to survive, expand, and renew itself after the eviction from Zuccotti Park (e.g. Castells 2012; Juris 2012). However, as Bennett (2012) points out, the growing impact of digital media on contemporary politics has likewise helped spawn a more personalized approach to political participation in which individuals are mobilized around 'personal action frames' rather than collective identities. This may be one reason why the OWS crowd remained fundamentally irreconcilable.

${ }^{5}$ Even the former editor of Adbusters Magazine and OWS co-founder, Micah White, describes the movement as a "constructed failure" (2016) because of its inability to achieve social change by engaging actively with the established system.
} 
words, until the chain of equivalences is turned into a prioritized chain of differences, the crowd cannot claim to have a politics. As she puts it:

The politics of the beautiful moment is no politics at all. Politics combines the opening with direction, with the insertion of the crowd disruption into a sequence or process that pushes one way rather than another. There is no politics until a meaning is announced and the struggle over this meaning begins. (Dean 2016, 125)

According to Dean, one way to make the crowd political is for it to crystallize into a political party that is capable of preserving the "egalitarian discharge", while simultaneously providing the crowd with a sense of direction. Only by doing so will the crowd move from being an opportunity for politics to becoming an actual political project (Dean 2016, 206). Even though Dean firmly believes that the Communist Party is best suited for assuming the task of institutionalizing the spirit of movements like OWS, she nonetheless suggests that any kind of (leftist) "movement party" will do. That is, a party that replaces the worn-out notion of a vanguard party with a party that provides a sense of political orientation while keeping open the space in which the crowd can picture itself as "the people" (Ibid., 229). In Laclauian terms, a movement party is thus a party that somehow manages to articulate particular objectives while maintaining some kind of universality. Coincidentally, since the rise and fall of OWS, a whole wave of such parties has swept across Europe: From Syriza in Greece and Podemos in Spain, to Movimento Cinque Stelle in Italy and LIVRE in Portugal. For the remainder of this analysis, we will explore the case of yet another movement party, namely a newly elected party in Denmark called The Alternative.

\subsection{The Alternative: From Movement to (Movement) Party}

In many ways, The Alternative began where OWS ended: With an almost infinite chain of equivalent grievances. In other words, while OWS ended up as a movement without demands, The Alternative began as such. At a press conference in November 2013, the former minister of culture in Denmark, Uffe Elbæk, and the head of a large umbrella organization for public sector workers, Josephine Fock, announced that they would be launching a new political project called The Alternative. The guiding idea behind The Alternative, they proclaimed, was to represent and promote social, economic, and environmental alternatives to the current state of affairs. However, to most people's surprise, Elbæk and Fock did not present any political program: "We don't have a grand party bible on the shelf", they told the press. Instead, they announced that the program would be developed during the following six months through a series of publically accessible "political laboratories". Through these laboratories, the goal was to arrive at concrete solutions to the most profound problems facing contemporary society and to figure out how to transform Denmark into "the place that we all dream of - a good society for everyone" (The Alternative 2013a).

Though no political program was presented at the press conference, Elbæk and Fock did provide some sense of direction by drawing attention to The Alternative's manifesto (The Alternative 2013b) and its six core values (Ibid. 2013c). Especially the manifesto, which, in the absence of concrete policy proposals, quickly became a main source of attraction for many supporters, is structured in much the same way as OWS' declaration. Even though it does not contain an equivalent sequence of grievance per se, the manifesto clearly testifies to the initial universality of The Alterna- 
tive's political project. Instead of listing a series of grievances and emphasizing that these grievances are not all-inclusive, The Alternative's manifesto begins with the encouraging statement: "There is always an alternative", and it ends with the following lines:

The Alternative is for you. Who can tell that something has been set in motion. Who can feel that something new is starting to replace something old. Another way of looking at democracy, growth, work, responsibility and quality of life. That is The Alternative.

Throughout the text, The Alternative is described as "a hope", "a dream", and as "a yearning" for sense and meaning. It is also described as a "shout out" against cynicism and as a "countermeasure" to the various crises facing the world and its future generations (The Alternative 2013b). Just like OWS' declaration, The Alternative's manifesto subscribes to the logic of universality for two reasons. First of all, it lends itself to multiple interpretations of what it actually means to be alternative. By proclaiming that there is always an alternative, and by stressing that The Alternative is for anyone who can feel that "something new" is about to replace "something old", the manifesto allows an incredibly wide range of (counter-hegemonic) identities to identify with The Alternative. In that way, The Alternative assumes the task of representing all those who feel a need for change, and in doing so, 'The Alternative' automatically becomes a universal identity and, hence, an empty signifier without any explicit claim to particularity.

Secondly, the manifesto establishes an antagonistic frontier between The Alternative and its constitutive outside. As mentioned in the theory section, empty signifiers are important to politics because they manifest a divide of the social into two opposing camps: 'the people' and its Other (Laclau 1994; 2006). In the manifesto, this is done in a more subtle way than in OWS' declaration, where this division is quite clearly expressed. However, by positioning The Alternative as a countermeasure to the old way of perceiving "democracy, growth, responsibility and quality of life", a frontier is erected between 'the new', as represented by The Alternative, and 'the old', as represented by the establishment. As such, even though the language of 'the people' vs. 'the establishment' is never explicitly appropriated, the universality of The Alternative's project is thoroughly solidified by the manifesto's dialectic rhetoric of new and old, which - intentionally or not - quickly translates into a dialectic of us and them. This constitutive negativity towards the establishment is further emphasized elsewhere in the manifesto where the need to "take back ownership of the economy and of democratic decisions" is articulated (The Alternative 2013b).

Through the manifesto, it becomes clear how The Alternative began as an incredibly universal project with no particular objectives; and this, combined with the lack of institutional representation, is the main reason why we conceive of The Alternative in its initial stage as a radical movement. ${ }^{6}$ However, as Elbæk and Fock promised at the

\footnotetext{
${ }^{6}$ What we mean by this is that, in the beginning, a movement logic was dominant in the Alternative. It is thus important to note that our conception of a movement differs from more traditional ones. While, for instance, Tilly and Wood $(2012,4)$ define a (social) movement as a synthesis of campaigns, repertoires, and so-called "WUNC displays", we conceptualize the logic of a (radical) movement as the grouping of loosely organized identities, tied together in equivalential chains and united against a common adversary. Hence, it matters less whether
} 
press conference, a political program was to be expected. Hence, in the early weeks of 2014, more than 20 political laboratories were organized, and through these events, more than 700 people participated in the process of crafting Denmark's first "open-source" political program (The Alternative 2016). In late May, the program was accepted at the party's first general assembly and then presented to the public. At that point, the program contained a series of proposals revolving around six core policy areas (Ibid. 2014). However, The Alternative's political program was far from finished. During the remainder of 2014 and the beginning of 2015, more laboratories were organized and more proposals were added to the program. Besides organizing political laboratories and staging various happenings, however, members of The Alternative spend most of their time collecting signatures in order to become eligible to run for parliament. On March 3, 2015, they succeeded in reaching the threshold of 20,260 signatures, which allowed The Alternative to register as an official contender for seats in the Danish parliament. Not only did this mark the formal transformation from movement to party, it likewise made The Alternative's members much more focused on the upcoming elections: Campaign strategies were prepared, key policy areas were selected and, most importantly, more proposals were added to the program (Ibid. 2015a).

At the national elections in June 2015, The Alternative earned an unexpected 4.8 percent of the votes, which translated into nine seats in the Danish parliament. At that point, the political program had grown significantly, and it now contained 64 pages of highly specific policy proposals (Ibid. 2015b). In fact, this easily made The Alternative's political program the most detailed program across all nine parties in the Danish parliament. Not only is The Alternative's program now the longest and most detailed program in parliament, it likewise contains a range of very elaborate and sometimes rather controversial proposals, such as offering unconditional basic income to unemployed citizens (proposal 4.3.1), legalizing assisted euthanasia (proposal 9.7.4), and releasing bionoxes into state-owned forests as a way of enhancing biodiversity (proposal 3.3.1). As such, it no longer makes sense to speak of The Alternative as a universal project. In fact, more than any other party, The Alternative positions itself as a highly particularized project; and in doing so, it thus abandons the task of representing the pure being of 'the people' as a whole. Paraphrasing Hobsbawm (1996), one could argue that The Alternative is no longer for everyone.

This process of particularization poses a problem for The Alternative because it invariably entails a narrowing of the scope of representation. Today, The Alternative is no longer defined solely through its opposition towards the establishment, which essentially means that the equivalential chain has been cut short, and that the logic of (positive/particular) differences becomes dominant (Laclau 2005, 72). But how then might we still characterize The Alternative as a radical party? Does the loss of universality not automatically cancel the party's radical identity? In the case of The Alternative, the answer seems to be: No. First of all, one would assume that particularization entailed a decrease in registered memberships. It seems logical to assume that once the party goes from representing 'the people' to representing a particular constituency, a certain amount of identities would cease to identify with the overall project. However, this has in no way been the case. In fact, The Alternative has sextupled their membership base in only one year (Juul 2016). Furthermore, in terms of opinion polls, the party has likewise increased its numbers: From 0.2 percent four

a movement has a certain size or whether its participants are committed or not. In relation to the present paper, the logic that structures the group is more important. 
months prior to the elections to 7.1 percent at the time of writing (Berlingske 2016). Secondly, through one and a half years of qualitative data collection conducted by the first author, it has become clear that those members who could be expected to feel marginalized by and large remain supporters of The Alternative's political project, regardless of political disagreements. As one member put it during a discussion on a Facebook page associated with The Alternative:

I don't need to agree with the party's policy in that many areas to believe in the project. The most important thing for me is that it's a product of pure democratic debate without dogmatism. To me, it's a strength that we maintain a curious disagreement all the way through the party, and that we don't lock ourselves into political programs.

It thus seems as if The Alternative has somehow managed to maintain a degree of universality while going through a process of particularization; a universality that allows the equivalential chain to expand despite the party's sudden claim to particularity. As such, The Alternative seems to meet the requirements for a so-called "movement party" (Dean 2016, 229). However, further research is needed in order to explore how and why that is made possible: Are we witnessing a simple case of "impure" representation (Laclau 2005, 155) in which identity flows, not from represented to representative, but also the other way around? Or has The Alternative, in fact, managed to postpone or displace the problem of particularization by somehow masking the existence of a gap between the universal and the particular?

\section{Conclusion: Of Movements and Parties}

When political projects, such as The Alternative in Denmark or Podemos in Spain, channel the energy of popular mobilizations into the parliamentary system, they engage with the state in much the same way that many scholars have prescribed (e.g. Dean 2016; Mouffe 2009; White 2016). This engagement, however, comes at a cost. By substituting negativity and otherness for a positive articulation of political objectives, they replace the logic of equivalence with a logic of difference in which political demands are clearly separated and hierarchically prioritized (i.e. by selecting key campaign issues). This means that they effectively remove the 'counter' from an otherwise counter-hegemonic project, and in doing so, they risk compromising their radical identity. As such, political parties like The Alternative cannot be conceived as alternatives to movements like OWS but as a necessary supplement. We thus disagree with those who claim that OWS was a failure because of its inability to pose demands. There is clearly something valuable in maintaining a universal stance against the hegemony of dominant discourses, such as neoliberalism and the progrowth agenda. That being said, we do agree with the critique levelled against the movement's unwillingness to forge strategic alliances with parts of the established system. As Mouffe $(2009,237)$ explains:

It's a 'war of positions' that needs to be launched, often across a range of sites, involving the coming together of a range of interests. This can only be done by establishing links between social movements, political parties and trade unions, for example. The aim is to create common bond and collective will, engaging with a wide range of 
sites, and often institutions, with the aim of transforming them. This, in my view, is how we should conceive the nature of radical politics.

Following that argument, the task for contemporary radical politics is neither to fully withdraw from nor to fully engage with the state. The task is, in our view, to forge links and alliances between various parts of what Urban (2009) has called the "mosaic left". That is, a left that consists of multiple entities that share a common goal but operate at different levels and according to different logics. For instance, while political parties are forced to engage in realpolitik through highly particularized negotiations and compromises with opposing parties, interest lobbies, and the media, movements are free to operate at a much more universal level by advocating and prefiguring alternative futures that transcend the oftentimes paralyzing cul-de-sac of parliamentary politics. Building on that conclusion, we thus propose a conceptual distinction between 'radical movements' and 'radical parties'. While the former is constituted by a potentially infinite chain of equivalent grievances (as was the case with OWS and the initial stage of The Alternative), the latter is constituted by a prioritized set of differential demands (as is the case with The Alternative today). This distinction allows us to view both movements and parties as vital parts of contemporary radical politics, as long as they remain discrete entities and refrain from collapsing into one single organizational form. Failing to maintain that distinction would most likely mean the end of universality.

However, as mentioned above, despite the recent transformation from movement to party, The Alternative has somehow managed to maintain a degree of universality in the face of rapid particularization. How and why that is the case remains to be fully explored. The most straightforward answer seems to be that The Alternative has found a way to bridge the otherwise unbridgeable gap between the universal and the particular. But, as explained in the theory section, that is simply not possible. At least in democratic societies, the chasm between universality and particularity must be kept open, as the conflation of the two levels would entail an immediate regression into the world of totalitarianism. Another explanation might be that young opposition parties, such as The Alternative, are less affected by the demand for particularization - at least as long as they maintain an oppositional stance and refrain from passing bills and striking compromises. This has, however, not been The Alternative's strategy. In fact, through the notion of a 'new political culture', which has been one of the party's trademark ideas, The Alternative has made it a virtue to collaborate with opposing parties and to enter productive negotiations despite political differences.

This leads us to the conclusion that The Alternative, rather than bridging and/or avoiding the gap, has found a way to mask or displace the very existence of a gap, which ultimately prevents it from collapsing into one organizational form. Further research is needed to explore how this is done in practice: What political strategies, organizational practices, or managerial technologies have assisted The Alternative in maintaining the ongoing production emptiness that is so vital to radical politics, while simultaneously engaging with the state? And more importantly perhaps, what political and organizational consequences does this have for all those radical parties that are currently flourishing across the European continent?

\section{References}

Adbusters. 2011a. \#Occupywallstreet: A Shift in Revolutionary Tactics. Accessed May 18, 2016. www.micahmwhite.com/occupywallstreet/ 
Adbusters. 2011b. Ballerina and Bull OWS Poster. Accessed May 18, 2016. www.micahmwhite.com/occupywallstreet/

Bennett, W. Lance. 2012. The Personalization of Politics: Political Identity, Social Media, and Changing Patterns of Participation. The ANNALS of the American Academy of Political and Social Science 644 (1): 20-39.

Berlingske. 2016. Berlingske Barometer. Accessed April 10, 2016. http://www.politiko.dk/barometeret

Brown, Trent. 2016. Sustainability as Empty Signifier: Its Rise, Fall, and Radical Potential. Antipode 48 (1): 115-133.

Butler, Judith. 2012. So what are the Demands? And here do they go from here? Tidal: Journal of Occupy Theory 2 (1): 8-11.

Castells, Manuel. 2012. Networks of Outrage and Hope: Social movements in the internet age. Cambridge: Polity Press.

Chomsky, Noam. 2012. Occupy. London: Penguin.

Dean, Jodi. 2012a. The Communist Horizon. London: Verso.

Dean, Jodi. 2012b. Occupy Wall Street: After the Anarchist Moment. Socialist Register 49: 52-62.

Dean, Jodi. 2016. Crowds and Party. London: Verso.

Deseriis, Marco and Jodi Dean. 2012. A Movement without Demands? Possible Futures, January 3.

Epstein, Barbara. 2012. Occupy Oakland: The Question of Violence. Socialist Register 49: 63-83.

Flyvbjerg, Bent. 2006. Five Misunderstandings about Case-Study Research. Qualitative Inquiry 12 (2): 219-245.

Gitlin, Todd. 2012. Occupy Nation: The Roots, the Spirit, and the Promise of Occupy Wall Street. New York: it Books.

Graeber, David. 2012. Occupy Wall Street's Anarchist Roots. In The Occupy Handbook, edited by Jane Byrne. New York: Back Bay Books.

Graeber, David. 2013. The Democracy Project: A History, a Crisis, a Movement. London: Allen Lane.

Gramsci, Antonio. 1971. Selections from the Prison Note Books of Antonio Gramsci. New York: International Publishers.

Hardt, Michael and Antonio Negri. 2004. Multitude: War and Democracy in the age of empire. New York: Penguin Press.

Hardt, Michael and Antonio Negri. 2011. The Fight for 'Real Democracy' at the Heart of Occupy Wall Street. Foreign Affairs, October 11.

Hobsbawm, Eric. 1996. Identity Politics and the Left. New Left Review 217 (1): 38-47.

Husted, Emil. 2015. From Creation to Amplification: Occupy Wall Street's Transition into an Online Populist Movement. In Civic Engagement and Social Media: Political Participation beyond the Protest, edited by Julie Uldam and Anne Vestergaard. Basingstoke: Palgrave Macmillan.

Juris, Jeffrey S. 2012. Reflections on \#Occupy Everywhere: Social media, Public Space, and Emerging Logics of Aggregation. American Ethnologist 39 (2): 259-279.

Juul, Trine. W. 2016. Alternativet Stormer Frem - Også på Landet. DR, April 1.

Kang, Susan. 2013. Demands Belong to the 99\%? The Conflict over Demands, Issues, and Goals in OWS. In Occupying Political Science: The Occupy Wall Street Movement from New York to the World, edited by Emily Welty, Matthew Bolton, Meghana Nayak and Christopher Malone. New York: Palgrave Macmillan.

Kroll, Andy. 2011. How Occupy Wall Street Really Got Started. In This Changes Everything: Occupy Wall Street and the 99\% Movement, edited by Sarah van Gelder and Staff of YES! Magazine. San Francisco, CA: Berrett-Koehler Publishers.

Laclau, Ernesto. 1977. Politics and Ideology in Marxist Theory. London: Verso. 
Laclau, Ernesto. 1985. New Social Movements and the Plurality of the Social. In New social Movements and the State in Latin America, edited by David Slater. Amsterdam: CEDLA.

Laclau, Ernesto. 1994. Why Do Empty Signifiers Matter to Politics? The Lesser Evil and the Greater Good, edited by Jeffrey Weeks. London: Rivers Oram Press.

Laclau, Ernesto. 1996a. Subject of Politics, Politics of the Subject. In Emancipation(s), edited by Ernesto Laclau. London: Verso.

Laclau, Ernesto. 1996b. Universalism, Particularism and the Question of Identity. In Emancipation(s), edited by Ernesto Laclau. London: Verso.

Laclau, Ernesto. 1997. The Death and Resurrection of the Theory of Ideology. MLN 112 (3): 297-321.

Laclau, Ernesto. 2001. Democracy and the Question of Power. Constellations 8 (1): 3-14.

Laclau, Ernesto. 2005. On Populist Reason. London: Verso.

Laclau, Ernesto. 2006. Why Constructing a People is the Main Task of Radical Politics. Critical Inquiry 32 (4): 646-680.

Laclau, Ernesto and Chantal Mouffe. 1985. Hegemony and Socialist Strategy: Towards a Radical Democratic Politics. London: Verso.

Laclau, Ernesto and Chantal Mouffe. 1987. Post-Marxism without Apologies. New Left Review 166 (1): 79-106.

Levitin, Michael. 2015. The Triumph of Occupy Wall Street. The Atlantic, June 10.

Maeckelbergh, Marianne. 2009. The Will of the Many: How the Alterglobalization Movement is Changing the Face of Democracy. London: Pluto Press.

Maharawal, Manissa M. 2013. Occupy Wall Street and a Radical Politics of Inclusion. The Sociological Quarterly 54 (2): 177-181.

Malone, Christopher and Violet Fredericks. 2013. OWS and US Electoral Politics: An Early Critical Assessment. In Occupying Political Science: The Occupy Wall Street Movement from New York to the World, edited by Emily Welty, Matthew Bolton, Meghana Nayak and Christopher Malone. New York: Palgrave Macmillan.

Miegel, Fredrik and Tobias Olsson. 2008. From Pirates to Politicians: The Story of the Swedish File Sharers Who Became a Political Party. In Democracy, Journalism and Technology: New Developments in an Enlarged Europe, edited by N. Carpentier, P. PruulmannVengerfeldt, K. Nordenstreng, M. Hartmann, P. Vihalemm, B. Cammaerts, H. Nieminen \& T. Olsson. Tartu: Tartu University Press.

Mouffe, Chantal. 2005. On the Political. New York: Routledge.

Mouffe, Chantal. 2009. The Importance of Engaging the State. In What is Radical Politics Today?, edited by Jonathan Pugh. Basingstoke: Palgrave Macmillan.

Newman, Saul. 2007. Unstable Universalities: Poststructuralism and Radical Politics. Manchester: Manchester University Press.

Occupy. 2011. The Declaration of the Occupation of New York City. Accepted by the NYC General Assembly, 29 September.

Ostroy, Andy. 2012. The Failure of Occupy Wall Street. Huffington Post, May 31.

Perlstein, Rick. 2012. Why Occupy Need to Start Making Demands. Rolling Stone, March 22.

Pickerill, Jenny and John Krinsky. 2012. Why Does Occupy Matter? Social Movement Studies 11 (3-4): 279-287.

Roberts, Alasdair. 2012. Why the Occupy Movement Failed. Public Administration Review 72 (5): 754-762.

Taylor, Blair. 2013. From Alterglobalization to Occupy Wall Street: Neoanarchism and the New Spirit of the Left. City 17 (6): 729-747.

The Alternative. 2013a. Press conference: Launch of The Alternative. Accessed May 18, 2016. http://www.dr.dk/nyheder/politik/video-uffe-elbaek-praesenterede-sit-nye-parti

The Alternative. 2013b. Manifesto. Accessed May 18, 2016. https://en.alternativet.dk/manifesto/

The Alternative. 2013c. Our Values. Accessed May 18, 2016. https://en.alternativet.dk/values/ 
The Alternative. 2014. First Draft of the Party Program. Accessed May 18, 2016. http://www.altinget.dk/misc/Alternativets Partiprogram - UDKAST.pdf

The Alternative. 2015a. Party Program. Accessed May 18, 2016: http://alternativet.dk/partiprogram/

The Alternative. 2015b. The Alternative is Ready for the Elections. Accessed May 18, 2016. http://alternativet.dk/valg-tema/

The Alternative. 2016. The History of The Alternative. Accessed May 18, 2016. http://alternativet.dk/alternativets-historie/

Tilly, Charles and Lesley J. Wood. 2012. Social Movements 1768-2012. Boulder: Paradigm Publishers.

Tønder, Lars and Lasse Thomassen, eds. 2005. Radical Democracy: Politics Between Abundance and Lack. Manchester: Manchester University Press.

Torfing, Jacob. 1999. New Theories of Discourse: Laclau, Mouffe and Žižek. Oxford: Blackwell Publishers.

Urban, Hans-Jürgen. 2009. Die Mosaik-Linke: Vom Aufbruch der Gewerkschaften zur Erneuerung der Bewegung. Blätter Für Deutsche Und Internationale Politik 5 (1): 71-78.

van Gelder, Sarah, ed. 2012. This Changes Everything: Occupy Wall Street and the 99\% Movement. San Francisco: Berrett-Koehler.

Welty, Emily, Meghana Nayak and Nick Zukowski. 2013. Occupy Wall Street as a Palimpsest: Overview of a Dynamic Movement. In Occupying Political Science: The Occupy Wall Street Movement from New York to the World, edited by Emily Welty, Matthew Bolton, Meghana Nayak and Christopher Malone. New York: Palgrave Macmillan.

White, Micah. 2016. The End of Protest: A Playbook for Revolution. Toronto: Knopf Canada. Young, Iris. 1990. Justice and the Politics of Difference. Princeton: Princeton University Press.

\section{About the Authors}

\section{Emil Husted}

Emil Husted is a $\mathrm{PhD}$ fellow at the Department of Organization, Copenhagen Business School. His core research interest centres on the notion of 'political organizing' in radical politics and how radical political parties manage the process of entering parliament without losing legitimacy and support. Specifically, he investigates radical political parties, such as The Alternative in Denmark and Podemos in Spain, and their efforts to institutionalize radical politics through parliament. Furthermore, Emil is vice chair of the Danish Association of Media Researchers and editorial board member of the peer-reviewed journal Politik.

\section{Allan Dreyer Hansen}

Allan Dreyer Hansen is associate professor at the Department of Social Sciences and Business at Roskilde University, Denmark. He has published widely on the discourse theory of Laclau and Mouffe, including 'Laclau and Mouffe and the Ontology of Radical Negativity' and 'Discourse, the Political and the Ontological Dimension: An Interview with Ernesto Laclau' (with André Sonnichsen) both in Distinktion, 2014. 